\title{
RESEÑA
}

\section{Cristos y cruces en la cosmovisión otomí de Ixmiquilpan, Hidalgo}

Manuel Alberto Morales Damián*

GALICIA GORDILLO, Angélica y SÁNCHEZ VÁZQUEZ Sergio, 2002, Cristos y cruces en la cosmovisión otomí de Ixmiquilpan, Hidalgo. Pachuca: Universidad Autónoma del Estado de Hidalgo.

Introducirse en la intimidad de una comunidad y realizar un esfuerzo por comprender su forma de explicar el mundo es labor de la antropología. En esta línea, Angélica Galicia y Sergio Sánchez Vázquez realizan un profundo y enriquecedor trabajo antropológico al invadir -con el consentimiento expreso de los actores- el espacio ritual de grupos otomíes del Valle del Mezquital. Cristos y cruces en la cosmovisión otomí de Ixmiquilpan, Hidalgo, permite hacer un recorrido por el ciclo festivo de los otomíes de este municipio y en él descubrir los mecanismos, a través de los cuales se produce y reproduce la identidad cultural otomí.

Centrados en explorar las fiestas de los cristos y las cruces, investigan especialmente las celebraciones del Señor de Jalpa en Ixmiquilpan, el Señor del Buen Viaje en Orizabita y el Señor del Buen Viaje en El Defay. El texto está organizado en cuatro partes: "Antecedentes históricos de la región", "Los cristos y las cruces", "Los cristos y las vírgenes" y "Reproducción de identidad y las fiestas". Así, estructurado el texto, se hace evidente que el enfoque metodológico de Galicia y Sánchez es etnohistórico; por ello en la primera parte dan cuenta de la evolución histórica que permite comprender a las actuales comunidades otomíes ixmiquilpenses; pero, en este sentido, una de sus aportaciones clave es hacer explícito el proceso sincrético a través del cual la herencia prehispánica y la colonial produjeron las actuales creencias otomíes acerca de sus Cristos y sus cruces. Creencias prehispánicas acerca del árbol cósmico -representado en forma cruciforme- dialogan, se confrontan y se funden con las creencias cristianas del siglo XVI y gestan una religiosidad diferente: la religión otomí colonial.

Tras las formas católicas de vírgenes, santos, cruces y cristos, se expresa una sustancia que no es católica, debemos añadir que tampoco es prehispánica. Se trata de una religiosidad colonial en la que prevalece un principio cosmológico: la bipolaridad. Ésta se expresa en la complementariedad entre Cielo y Tierra o Sol y Luna, convirtiéndose en la creencia en una pareja divina primordial: los viejos padre y madre, $\mathrm{Zi}$ dada y $\mathrm{Zi}$ nana, cuya réplica terrenal se encuentra en el matrimonio entre Cristo y la Virgen. Claro está que la presencia de una pareja divina implica la existencia de una familia sagrada en la cual las imágenes de vírgenes y cristos en las diversas iglesias de la zona otomí establecen relaciones fraternales o matrimoniales. 
* Doctor en Estudios Mesoamericanos y Licenciado en Historia por la UNAM. Miembro del Sistema Nacional de Investigadores, nivel 1. Profesorinvestigador del Área Académica de Historia y Antropología, UAEH. mmorales@uaeh.reduaeh.mx

Galicia y Sánchez muestran en forma transparente cómo la organización los dioses y santos responde a la lógica social del grupo étnico. Puesto que, a través de las tradiciones religiosas se establecen lazos sociales, se marcan los límites territoriales de cada una de las comunidades, se justifican y se validan los principios morales a través de los cuales funciona el entramado social otomí.

Un último aspecto destacado del trabajo antropológico de Galicia y Sánchez es que establecen la presencia de un ciclo calendárico que determina las festividades de Ixmiquilpan. Las fiestas religiosas son concebidas como un contrato entre los hombres y las divinidades, contrato que salvaguarda el orden cósmico puesto que hombres y dioses se necesitan mutuamente. Así, por ejemplo, la satisfacción de los dioses a través de la ofrenda garantiza la salud y la prosperidad y, por el contrario, su descontento ante las ofrendas produce el rompimiento del equilibrio generando enfermedad e incluso muerte. En este sentido Galicia y Sánchez afirman: "santos -o dioses-, maíz y hombres son elementos complementarios en la cosmovisión otomí. Sin hombres no habría santos, sin santos no habría alimentos, sin alimentos no habría hombres. Es un circuito de situaciones indivisibles".

El trabajo realizado por Galicia y Sánchez revela minuciosidad en el análisis de la información documental y una empatía poco común al entablar las relaciones con el grupo humano sujeto de su investigación. Galicia y Sánchez nos permiten reconocer la riqueza de las creencias religiosas otomíes y los mecanismos a través de los cuales estas creencias sirven para mantener la unidad social y cultural en este municipio hidalguense. 